\title{
The Paris Agreement and Montenegro's INDC: Assessing the Environmental, Social, and Economic Impacts of Selected Investments
}

\author{
Gordana Djurovic $^{1 *}$, Jasmina Cetkovic ${ }^{1}$, Vasilije Djurovic ${ }^{1}$, Nebojsa Jablan² \\ ${ }^{1}$ Faculty of Economics, University of Montenegro, Jovana Tomasevica 37, 81000 Podgorica, Montenegro \\ ${ }^{2}$ Crnogorski Elektroprenosni Sistem AD, Bul. Sv. Petra Cetinjskog 18, 81000 Podgorica, Montenegro
}

Received: 24 July 2017

Accepted: 6 August 2017

\begin{abstract}
At the 2015 Paris Climate Conference of the Parties of UNFCCC a legally binding and universal agreement on climate was adopted. The Paris agreement covers the period from 2020 onward and presents an action plan to limit global warming "well below" $2^{\circ} \mathrm{C}$ and to pursue efforts to limit it to $1.5^{\circ} \mathrm{C}$. Montenegro's contribution to the international effort to avoid dangerous climate change is expressed in the Intended Nationally Determined Contribution (INDC) of Montenegro - at minimum a 30\% emission reduction by 2030 compared to the 1990 base year. In line with its INDC, the priority investment plan has been prepared, accompanied by socio-economic analysis that includes the environmental, social, and economic impact assessment of selected investments. The conducted analysis confirmed the research questions. Firstly, by selecting priority investments in the period 2017-2030, Montenegro achieves the set target of reducing the GHG emissions given in Montenegro's INDC (33.5\%). Secondly, total net effects of selected investments in Montenegro for achieving INDC are positive for the wider community, as confirmed by the performance indicators of the selected projects obtained through the CBA (NSV, IRR, and B/C). Finally, priority investments are fully in line with the national development framework, sector priorities, and the EU accession process.
\end{abstract}

Keywords: Paris Agreement, Montenegro, GHG reduction, investment, socio-economic analysis

\section{Introduction}

After 25 years of UN climate diplomacy, the world's governments have for the first time in history negotiated a treaty that envisages climate action by all countries [1]. Namely, 2015 COP21, also known as the 2015 Paris Climate Conference of the Parties of UNFCCC (United

*e-mail: gordana@t-com.me
Nation Framework Convention on Climate Change), which was held in Paris from 30 November to 12 December 2015 , is a legally binding and universal agreement on climate. The Paris agreement presents an action plan to limit global warming 'well below' $2^{\circ} \mathrm{C}$ and to pursue efforts to limit it to $1.5^{\circ} \mathrm{C}$. It covers the period from 2020 onwards [2]. The Paris agreement is a major step toward a better implementation of joint actions at the global level and accelerates the global transformation in society with low $\mathrm{CO}_{2}$ emissions, resistant to climate change. The Paris Agreement entered into force on 4 November 2016 
(30 days after ratification by at least 55 countries accounting for at least $55 \%$ of global greenhouse gas emissions, or GHG). By mid July 2017, the Agreement had been ratified in 153 countries out of 197 parties [3]. The process of ratification is also in a final phase in Montenegro.

Contrary to the Kyoto Protocol [4], which implied the obligation to reduce emissions for a number of developed countries, the Paris Agreement introduced a quantified emission reduction obligation for all Parties to the Convention. The Paris Agreement outlines, among other things, who should reduce GHG emissions and who should pay for those reductions [5]. In other words, the agreement follows UN climate change politics and introduces the principle of equity and the norm of common but differentiated responsibilities (CBDR) and respective capabilities in light of different national circumstances [2]. In general terms, CBDR dictates that all countries have a shared responsibility to address climate change. However, because different countries have contributed different amounts to the climate change problem and have different capacities to address it, they should have different obligations related to, for example, emission reductions, climate finance, technology transfer, and capacity building [6]. The Parties also agreed to communicate every five years their contributions in order to set more ambitious targets. They also accepted the idea of reporting to each other and to the public on how well they are doing to implement their targets in order to ensure transparency and oversight [2]. Finally, the most important element of the Paris Agreement is the principle of solidarity. The EU and other developed countries will continue to provide climate finance to assist developing countries both in reducing emissions and building resilience to climate change impacts. The EU and its member states are committed to scaling up the mobilization of climate finance as part of a global effort led by developed countries [7].

Montenegro is a predominantly mountainous country in southeastern Europe, but also a Mediterranean country with 623,000 inhabitants and GDP per capita in PPS in 2016 of $42(E U=100)$ [8]. The total surface area is 13,812 $\mathrm{km}^{2}$, while its Adriatic Sea coastline is $293 \mathrm{~km}$ long [9]. At the same time, Montenegro is a candidate country that opened accession talks with the EU in June 2012. As a country of the EU enlargement, Montenegro is obliged to harmonize its legislation with the EU Acquis and to fully implement it. In the area of climate change, the level of alignment is still limited and negotiating chapter 27 the environment will be open soon. The national strategy in the field of climate change by 2030 was adopted in September 2015 [10]. Hence Montenegro needs to ensure that the strategy is implemented in a way that is consistent with the EU 2030 framework on climate and energy policies and well integrated into all relevant sectors [11].

Montenegro is a non-Annex I country highly vulnerable to the effects of climate change. National emissions of greenhouse gases represent only $0.009 \%$ of global emissions and the net per capita GHG emissions in Montenegro was $7.25 \mathrm{tCO}_{2}$ eq in 2010 [12]. The Government of Montenegro submitted the Intended Nationally Determined Contribution (INDC) of Montenegro on 15 September 2015, following decision 1/ CP.19 and decision 1/CP.20 of the UNFCCC, which invited parties to communicate the UNFCCC Secretariat their INDCs, with the aim of achieving the ultimate objective of the UNFCCC as set out in Article 2 of the convention [13]. Montenegro's contribution to the international effort to avoid dangerous climate change is expressed through a minimum $30 \%$ emission reduction by 2030 compared to the 1990 base year. This goal is fair and ambitious, as well as in line with the obligation arising from the accession negotiation of Montenegro with the EU.

As presented in Table 1, the GHG emission level for Montenegro from sectors covered by INDC (energy, industrial processes, agriculture and waste, without sinks) was 5,239 kilotons in 1990, and Montenegro pledges to reduce it by at least by 1,572 kilotons to a level at or below 3,667 kilotons. Greenhouse gas emissions and removals from agriculture, forestry, and other land uses are currently not included in the accounting. Emissions and removals from these sectors can be included in the INDC at a later stage, when technical conditions allow for it.

Already in 2013, a significant reduction of GHG emissions was achieved by about $40 \%$ compared to the 1990 level. This was primarily achieved through the reduction of activity in the sector of industrial processes (Podgorica Aluminium Plant-KAP) and in the agriculture sector during the transition recession 1991-2000 and slow recovery in the period 2001-13. The general trend was not the same in all sectors. The share of emissions produced by the energy sector ranged from $22 \%$ in 1995 to $76 \%$ in 2013. The share of emissions produced through industrial processes ranged from 61\% in 1995 to only 9\% in 2013 due to continuous reduction of production in the metal industry. $\mathrm{CO}_{2}$ eq emissions produced by the agriculture sector ranged from $25 \%$ in 1994 to $9 \%$ in 2013 . The waste sector produced the least emissions with levels ranging from $0.4 \%$ in 1990 to $6.3 \%$ in 2013 .

Dynamic economic growth is expected in the period 2017-30, including growth in industrial processes (aluminium) and energy production. This trend will change the level of GHG emission reduction from $40 \%$ to around $33.5 \%$ by 2030 compared to the 1990 base year. This still means that Montenegro will fulfill its international obligation and make a national contribution to reducing the negative effects of the GHG emissions in 2030 compared to 1990 . The overall reduction presented in the INDC is to be achieved by general increase of energy efficiency, improvement of industrial technologies, increase of the share of renewables, and modernization in the power sector [12].

To prepare a plan of action for INDC achievement it is necessary to prioritize the main investments in sectors covered by the INDC and to estimate the specific environmental (in the area of climate changes), economic, and social impacts of this investment plan. The following 
Table 1. Total GHG emissions (without sinks) presented as $\mathrm{CO}_{2}$ eq emissions in the period 1990-2013 with projections to 2030 [10].

\begin{tabular}{|c|c|c|c|c|c|c|c|c|c|}
\hline \multirow{2}{*}{ Year } & \multicolumn{2}{|l|}{ Energy } & \multicolumn{2}{|c|}{ Industrial processes } & \multicolumn{2}{|c|}{$\begin{array}{l}\text { Agriculture and } \\
\text { land use }\end{array}$} & \multicolumn{2}{|l|}{ Waste } & \multirow{2}{*}{$\begin{array}{l}\text { Total emissions without } \\
\text { sinks }(100 \%) \\
\left(\mathrm{Gg} \mathrm{CO}_{2} \text { eq }\right)\end{array}$} \\
\hline & $\left(\mathrm{Gg} \mathrm{CO}_{2} \mathrm{eq}\right)$ & $\%$ & $\left(\mathrm{Gg} \mathrm{CO}_{2} \mathrm{eq}\right)$ & $\%$ & $\left(\mathrm{Gg} \mathrm{CO}_{2} \mathrm{eq}\right)$ & $\%$ & $\left(\mathrm{Gg} \mathrm{CO}_{2} \mathrm{eq}\right)$ & $\%$ & \\
\hline 1990 & $2,352.61$ & 45 & $2,272.87$ & 43 & 593.42 & 11 & 19.62 & 0.4 & $5,238.52$ \\
\hline 1991 & $2,450.28$ & 41 & $2,909.18$ & 49 & 591.06 & 10 & 34.97 & 0.6 & $5,985.49$ \\
\hline 1992 & $1,809.33$ & 42 & $1,891.39$ & 44 & 553.59 & 13 & 45.41 & 1.1 & $4,299.72$ \\
\hline 1993 & $1,602.90$ & 55 & 709.60 & 24 & 530.71 & 18 & 57.43 & 2.0 & $2,900.64$ \\
\hline 1994 & $1,428.09$ & 67 & 94.12 & 4 & 539.7 & 25 & 68.97 & 3.2 & $2,130.88$ \\
\hline 1995 & 825.24 & 22 & $2,272.87$ & 61 & 564.24 & 15 & 80.39 & 2.1 & $3,742.74$ \\
\hline 1996 & $1,842.40$ & 66 & 294.48 & 11 & 559.66 & 20 & 91.69 & 3.3 & $2,788.23$ \\
\hline 1997 & $1,850.80$ & 46 & $1,547.59$ & 38 & 539.81 & 13 & 105.17 & 2.6 & $4,043.37$ \\
\hline 1998 & $2,259.86$ & 52 & $1,471.88$ & 34 & 533.09 & 12 & 116.04 & 2.6 & $4,380.87$ \\
\hline 1999 & $2,332.16$ & 50 & $1,648.27$ & 36 & 533.09 & 11 & 126.57 & 2.7 & $4,640.09$ \\
\hline 2000 & $2,427.50$ & 47 & $2,046.92$ & 40 & 545.34 & 11 & 136.79 & 2.7 & $5,156.55$ \\
\hline 2001 & $2,013.42$ & 42 & $2,173.09$ & 45 & 514.96 & 11 & 146.02 & 3.0 & $4,847.49$ \\
\hline 2002 & $2,517.68$ & 46 & $2,223.86$ & 41 & 519.87 & 10 & 154.39 & 2.9 & $5,415.80$ \\
\hline 2003 & $2,427.77$ & 49 & $1,846.00$ & 37 & 526.98 & 11 & 161.92 & 3.3 & $4,962.67$ \\
\hline 2004 & $2,388.09$ & 51 & $1,665.62$ & 35 & 504.09 & 11 & 168.61 & 3.6 & $4,726.41$ \\
\hline 2005 & $2,200.89$ & 51 & $1,544.11$ & 36 & 359.34 & 8 & 174.48 & 4.1 & $4,278.82$ \\
\hline 2006 & $2,356.22$ & 52 & $1,635.67$ & 36 & 347.65 & 8 & 179.63 & 4.0 & $4,519.17$ \\
\hline 2007 & $2,293.34$ & 50 & $1,769.81$ & 38 & 381.18 & 8 & 184.25 & 4.0 & $4,628.58$ \\
\hline 2008 & $2,904.72$ & 67 & 930.08 & 21 & 332.31 & 8 & 188.21 & 4.3 & $4,355.32$ \\
\hline 2009 & $1,979.14$ & 66 & 572.38 & 19 & 267.53 & 9 & 190.26 & 6.3 & $3,009.31$ \\
\hline 2010 & $2,725.54$ & 70 & 722.66 & 19 & 263.1 & 7 & 193.65 & 5.0 & $3,904.95$ \\
\hline 2011 & $2,768.15$ & 69 & 765.59 & 19 & 286.74 & 7 & 197.41 & 4.9 & $4,017.89$ \\
\hline 2012 & $2,684.24$ & 75 & 398.94 & 11 & 288.27 & 8 & 200.49 & 5.6 & $3,571.94$ \\
\hline 2013 & $2,415.87$ & 76 & 282.93 & 9 & 280.22 & 9 & 199.26 & 6.3 & $3,178.28$ \\
\hline \multicolumn{9}{|c|}{ Reduction by 2013 compared to $1990-2,060.24 \mathrm{Gg} \mathrm{CO}_{2} \mathrm{eq}$} & $39.3 \%$ \\
\hline \multicolumn{9}{|c|}{ Projection of GHG emissions in 2030} & $3,485.86$ \\
\hline \multicolumn{9}{|c|}{ Projected reduction of GHG emissions in 2030 compared to 1990} & $33.5 \%$ \\
\hline
\end{tabular}

economic analysis is prepared as an integral part of the process of ratification of the Paris Agreement in Montenegro.

Different models are used in the literature to simulate the effects of climate change on aggregate consumption, investment, and income [14]. Special attention has been paid to a financial approach to renewable energy production, integrating social, financial, and power production aspects in a goal programming model [15]. $\mathrm{CO}_{2}$ emissions, green management, and financial performance of socially responsible firms have also been studied [16]. At the same time, authors have tried to analyze the potential role that tariff policy may have in encouraging countries to participate in multilateral efforts to mitigate climate change [17-18], but also to reduce emissions and the negative impact on the environment in certain sectors [19-20]. It is not disputable that global climate change can be successfully solved only with a solid understanding of their economic dimensions [21]. Some studies, through combined cost and benefit analysis of technologies and strategies for addressing local air pollution and global climate change problems, have highlighted the relevance and interaction between these two current environmental challenges [22]. At the same time, recently researchers' efforts have been made to look at the use of low-carbon technologies with economic technologies through the 
socio-economic effects assessment of the use of such technologies (such as the effects of additional economic activities, creation of new jobs, environmental effects, etc.) [23].

The conducted socio-economic analysis of the priority investments justification for achieving Montenegro's INDC contribution for 2017-30 was carried out using cost-benefit analysis in order to assess the social benefits and social damages from investments. As an empirical technique for evaluating investment projects, cost-benefit analysis was first applied in the United States in the 1930s [24] in order to expand its use in other developed and less developed countries [25]. Unlike financial justification analysis which includes the calculation of the costs and benefits of the project itself for the investor, the socio-economic analysis of benefits and costs includes financial measurable and non-measurable elements of social benefits and damages [26]. Social benefits are mainly related to community development through a better economic environment, the preservation of the environment, or the welfare of the wider social community. In this regard, the decision on such projects is complex and requires an analysis of a large number of factors [27]. Adequate estimation of all costs and benefits of such projects enables decision-makers to select projects with the lowest costs and maximum benefits [28-29]. The cost-benefit analysis starts from the idea that the same effect does not have to be positive for both the investor and the wider social community, and their goals do not have to be always fully harmonized. In this regard there are some differences between the criteria for making investment decisions and methods for assessing the investment effects.

Traditional financial cost benefit analysis of justification of investments uses the rate of return of funds as the elimination criterion of project justification [30], without considering the costs and benefits that the project brings to society as a whole. This analysis serves as a testing tool for two specific factors relevant for assessing the justification of the investment (expected return on assets and expected risk) [31]. It can be used as an adequate assessment of the justification of commercial but not investment projects for which the net effects of the project are relevant for society as a whole. In these projects environmental, social, health, traffic, and other effects are very important, which significantly contribute to the achievement of the project's objectives. In this respect, as set out in Article 101 (information necessary for the approval of a major project) of Regulation (EU) No. 1303/2013 [32], socio-economic analysis of projects must be carried out in order to assess the contribution of the project to the wider community [33]. This is why the socio-economic objectives of project analysis have become key requirements in many projects supported by international financial institutions and EU funds.

\section{Materials and Methods}

\author{
Method of Choosing Priority Investments \\ in Order to Fulfil Montenegro's INDC by 2030 \\ and Research Questions
}

Priority investments are determined in relation to the key sectors included in the INDC document and the effects that these investments have on both reducing $\mathrm{GHG}$ emissions and increasing the share of renewable energy sources in final energy consumption, as well as energy efficiency projects. For each of the listed investments, the dynamics of investments as well as operational costs are determined.

Socio-economic investment analysis should answer two basic research questions:

- Does the selection of priority investments enable Montenegro to achieve the set goal of reducing GHG emissions given in the Intended Nationally Determined Contribution (INDC) of Montenegro?

- Are total net effects of selected investments in Montenegro for the INDC achievement positive in relation to the wider community?

In addition to basic research questions, this analysis should also address the following two derived questions:

- Are priority investments compatible with key sectoral strategic documents of Montenegro in the field of energy, and also climate change and sustainable development?

- Do the undertaken commitments simultaneously represent fulfilment of Montenegro's obligations from the EU accession negotiations in the field of the environment?

\section{Methodological Determinants for Socio-Economic Analysis of Justification of Investments}

Socio-economic analysis of the investment justification is carried out using the classical cost-benefit analysis (CBA), where on the one hand all investment and operating costs of priority projects are examined, and on the other hand all the socio-economic benefits that would arise from the realization of these projects. Thus determined costs and benefits are reduced to the present value by the discounting process. Their difference determines the net effects of the investments based on the projected net effect balance, before mentioned basic dynamic indicators of investment justifiability are determined.

The basic purpose of socio-economic analysis of project justification is to prove that the project has a positive net contribution/effect on the wider community (in order to achieve long-term sustainability including economic and wider social development) and that it is therefore worth implementing. In other words, socioeconomic analysis aims to assess the contribution of 


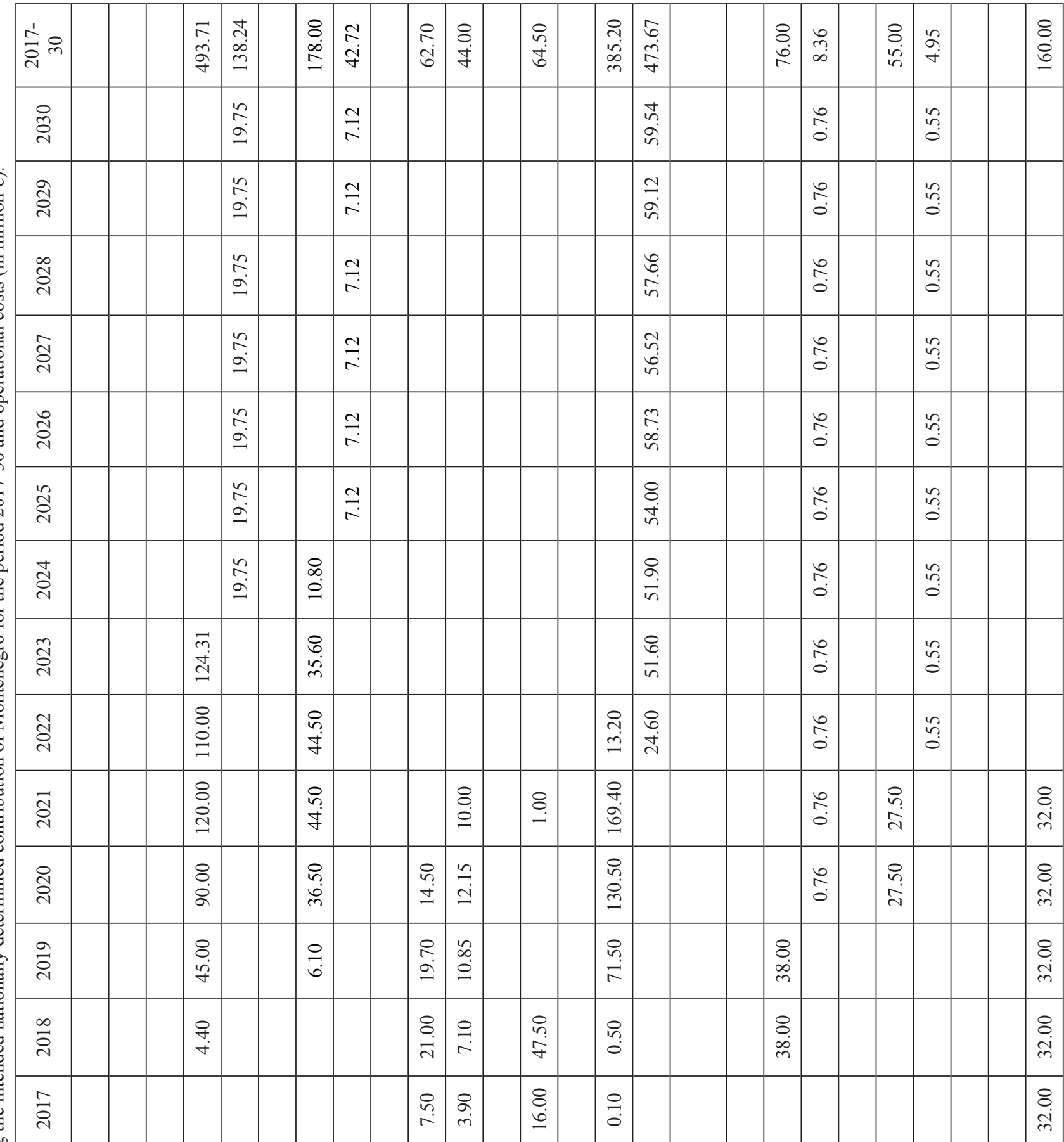

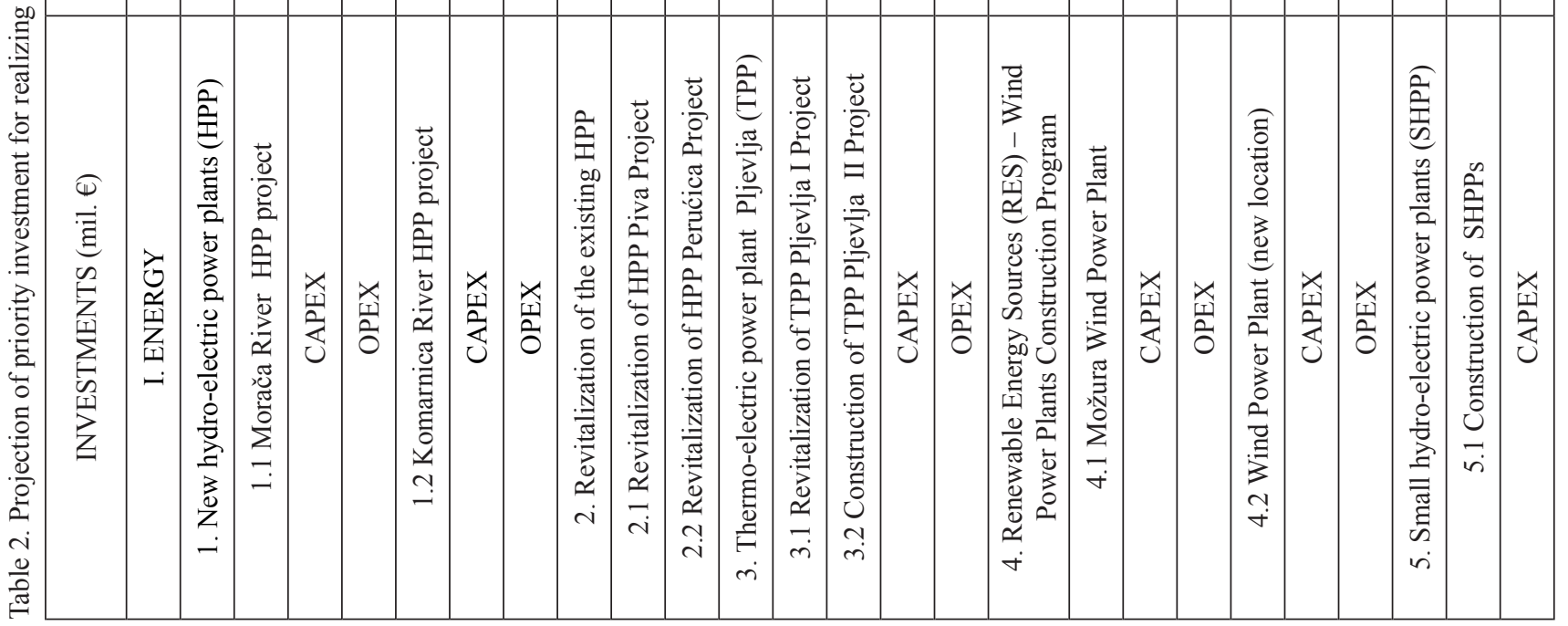




\begin{tabular}{|c|c|c|c|c|c|c|c|c|c|c|c|}
\hline $\begin{array}{l}\stackrel{\Upsilon}{1} \\
\stackrel{2}{2}\end{array}$ & $\begin{array}{l}8 \\
\stackrel{9}{9}\end{array}$ & $\begin{array}{l}8 \\
\stackrel{+}{+}\end{array}$ & & $\stackrel{\text { Iิ }}{\text {. }}$ & $\stackrel{\text { ণे }}{+}$ & & $\begin{array}{l}\dot{B} \\
\dot{\sigma} \\
\dot{\sigma}\end{array}$ & & $\underset{\sim}{\simeq}$ & 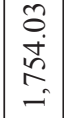 & 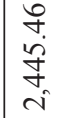 \\
\hline$\stackrel{8}{\stackrel{B}{-}}$ & & $\begin{array}{l}8 \\
\stackrel{0}{0}\end{array}$ & & & $\stackrel{m}{0}$ & & ત્రి & & $\underset{i}{8}$ & 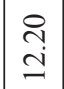 & $\begin{array}{l}n \\
\infty \\
\dot{0} \\
0\end{array}$ \\
\hline$\stackrel{8}{:}$ & & $\begin{array}{l}\stackrel{0}{0} \\
\stackrel{0}{0}\end{array}$ & & & $\stackrel{m}{0}$ & & ત્ণి & & $\underset{i}{8}$ & $\begin{array}{l}\stackrel{\mathrm{I}}{\mathrm{I}} \\
\mathrm{I}\end{array}$ & $\stackrel{?}{\stackrel{\rho}{\dot{\sigma}}}$ \\
\hline$\stackrel{8}{8}$ & & $\begin{array}{l}8 \\
\stackrel{0}{0}\end{array}$ & & & $\stackrel{m}{m}$ & & $\stackrel{P}{\stackrel{2}{2}}$ & & $\begin{array}{l}8 \\
i\end{array}$ & $\begin{array}{l}尺 \\
\stackrel{2}{g} \\
\dot{g}\end{array}$ & f \\
\hline$\stackrel{8}{\stackrel{8}{-}}$ & & $\begin{array}{l}8 \\
\stackrel{0}{0}\end{array}$ & & & $\tilde{m}$ & & 号 & & $\begin{array}{l}8 \\
i\end{array}$ & $\mid \begin{array}{l}0 \\
0 \\
ِ \\
0\end{array}$ & $\frac{m}{0}$ \\
\hline$\underset{-}{8}$ & & $\stackrel{8}{\circ}$ & & & $\stackrel{m}{?}$ & & $\begin{array}{l}\stackrel{n}{r} \\
\stackrel{+}{2}\end{array}$ & & $\begin{array}{l}8 \\
i \\
\text { in }\end{array}$ & $\begin{array}{l}0 \\
0 \\
0 \\
0\end{array}$ & $\begin{array}{l}\tilde{v} \\
\tilde{n} \\
\tilde{o}\end{array}$ \\
\hline$\underset{:}{\stackrel{8}{-}}$ & & $\stackrel{8}{\circ}$ & & & ? & & \begin{tabular}{l}
8 \\
\hdashline
\end{tabular} & & $\underset{i}{\stackrel{8}{0}}$ & $\mid \begin{array}{l}0 \\
n \\
0 \\
0\end{array}$ & $\begin{array}{l}\overrightarrow{0} \\
\dot{8}\end{array}$ \\
\hline$\stackrel{8}{:}$ & & $\begin{array}{l}\stackrel{0}{0} \\
\stackrel{\circ}{0}\end{array}$ & & & $\stackrel{m}{\tilde{o}}$ & & $\begin{array}{l}\stackrel{\sim}{r} \\
\dot{r}\end{array}$ & & 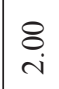 & 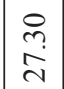 & $\begin{array}{l}\hat{a} \\
\tilde{a}\end{array}$ \\
\hline$\stackrel{8}{\stackrel{8}{-}}$ & & $\begin{array}{l}8 \\
\stackrel{0}{0}\end{array}$ & & & $\stackrel{m}{0}$ & & 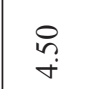 & & $\begin{array}{l}8 \\
i\end{array}$ & 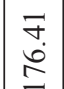 & $\frac{n}{n}$ \\
\hline$\stackrel{8}{\stackrel{8}{-}}$ & & $\stackrel{8}{\circ}$ & & & $\stackrel{m}{\tilde{o}}$ & & $\begin{array}{l}\stackrel{\wp}{r} \\
\stackrel{+}{*}\end{array}$ & & $\underset{i}{\stackrel{8}{0}}$ & $\mid \begin{array}{c}\stackrel{9}{1} \\
\dot{+} \\
\Phi\end{array}$ & $\begin{array}{l} \pm \\
0 \\
i \\
d\end{array}$ \\
\hline$\stackrel{8}{-}$ & & $\begin{array}{l}\stackrel{0}{0} \\
\stackrel{\circ}{0}\end{array}$ & & & $\stackrel{m}{\tilde{b}}$ & & $\begin{array}{l}\text { in } \\
+\end{array}$ & & 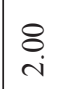 & 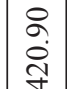 & $\begin{array}{l}\hat{n} \\
\tilde{y} \\
\tilde{y}\end{array}$ \\
\hline 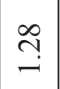 & & $\stackrel{8}{\stackrel{0}{9}}$ & & & m? & & 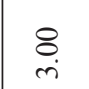 & & io & $\begin{array}{l}n \\
\infty \\
n\end{array}$ & $\begin{array}{l}\tilde{2} \\
\tilde{8} \\
8\end{array}$ \\
\hline$\stackrel{0}{0}$ & & $\stackrel{8}{\circ}$ & & & $\stackrel{m}{\tilde{b}}$ & & $\begin{array}{l}\stackrel{n}{i} \\
\text { in }\end{array}$ & & $\stackrel{g}{6}$ & 苞 & $\begin{array}{l}\hat{\beta} \\
\infty \\
\infty\end{array}$ \\
\hline $\begin{array}{l}0 \\
0 \\
0\end{array}$ & $\begin{array}{l}0 \\
\infty \\
\infty\end{array}$ & 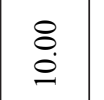 & & & $\stackrel{m}{0}$ & & in & & $\stackrel{8}{\stackrel{8}{0}}$ & 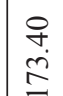 & $\stackrel{\tilde{m}}{\stackrel{5}{I}}$ \\
\hline ? & 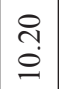 & $\begin{array}{l}8 \\
\stackrel{0}{0}\end{array}$ & & 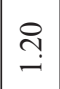 & & & $\underset{\sim}{\stackrel{8}{r}}$ & & $\begin{array}{c}\widetilde{1} \\
\infty \\
0\end{array}$ & $\mid \begin{array}{l}\mathbb{N} \\
\infty \\
\infty\end{array}$ & $\begin{array}{l}0 \\
\dot{0} \\
\dot{\infty}\end{array}$ \\
\hline $\begin{array}{l}x \\
\mathbf{1} \\
0 \\
0\end{array}$ & 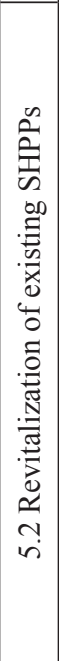 & 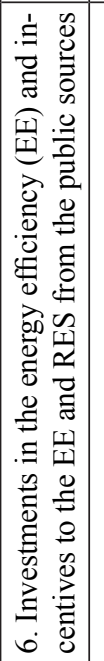 & 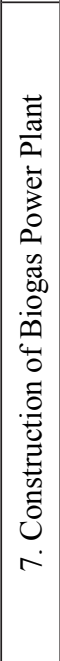 & 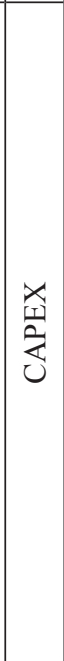 & 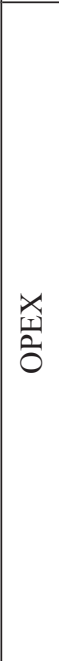 & 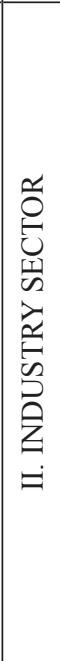 & 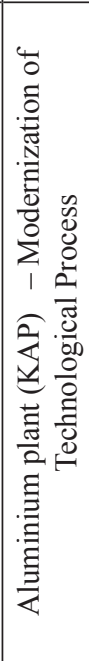 & 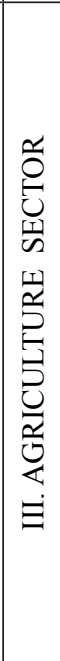 & 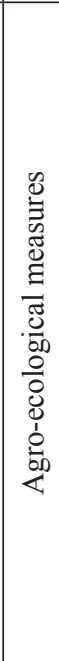 & 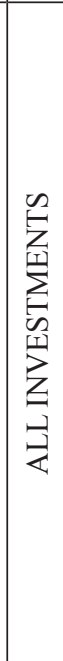 & 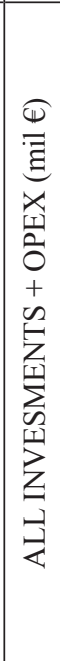 \\
\hline
\end{tabular}

selected projects to the general welfare of a particular society [32].

Determining the net effects of a project on the wider community requires a previously conducted analysis and budgeting of all relevant socio-economic costs and benefits of the project. The socio-economic benefits of the project should be greater than the socio-economic costs of the project, as confirmed by the positive economic net present value $(\mathrm{ENPV}>0)$; the economic benefits and costs ratio, which is greater than $1(\mathrm{~EB} / \mathrm{C}>1)$; and economic internal rate of return, which is greater than the established discount rate (EIRR > discount rate).

Based on the difference between the socio-economic benefits and the socio-economic costs of the project, net effects for the projected period 2018-40 were determined.

The basic methodological guidelines for implementing this socio-economic feasibility analysis are:

- Socio-economic analysis was conducted in accordance with the standards and principles of the EC and international financial institutions.

- In order to reduce socio-economic costs and benefits for the same base year (2018), a discounting process was performed. According to the EC Guide, when it comes to investments that are subject to this analysis, it is recommended to use a discount rate of $5 \%$ [33].

- Based on the difference between the socio-economic costs and the socio-economic benefits of the project, net effects for the projection period 2018-40 have been identified.

- On the basis of the net balance sheet, the indicators of socio-economic justification for the investments that are the subject of this analysis have been identified: economic net present value (ENPV), economic internal rate of return (EIRR), and economic benefit-cost ratio $(\mathrm{EB} / \mathrm{C})$.

\section{Results and Discussion}

In order to carry out the socio-economic analysis of priority investment for realizing Montenegro's INDC, the pre-calculation of investment and operating costs have been provided, and the dynamics of realization of investments determined, as shown in Table 2. Investment costs and operating costs constitute a sum of total expenditures in the period 2017-30 (extended until 2040 for the purpose of this analysis). Operating costs depend on the nature of the investment and are determined by the process of operation of installed equipment and other assets.

Operating costs in hydro-electric power plants (HPPs) were taken into consideration in accordance with the norm for hydroelectric power plants, which ranges from $2 \%$ to $4 \%$ of investment, with $4 \%$ being used for the purposes of this analysis. As for small hydroelectric power plants (SHPPs) and wind power plants, the norms for operational costs which refer to ensuring the reliability of the facility, and current and investment maintenance, which can satisfy the amount of $1 \%$ of the investment, 
Table 3. Calculation of climate benefits.

\begin{tabular}{|c|c|c|c|c|c|c|c|c|c|c|c|c|c|}
\hline PART ONE $(2018-2030)$ & 2018 & 2019 & 2020 & 2021 & 2022 & 2023 & 2024 & 2025 & 2026 & 2027 & 2028 & 2029 & 2030 \\
\hline GDP of Montenegro (in mil. $€$ ) & 4.114 & 4.292 & 4.471 & 4.690 & 4.927 & 5.193 & 5.473 & 5.769 & 6.081 & 6.409 & 6.755 & 7.120 & 7.504 \\
\hline \multicolumn{14}{|l|}{ INVESTMENTS } \\
\hline \multicolumn{14}{|l|}{ I. ENERGY SECTOR } \\
\hline \multicolumn{14}{|l|}{$\begin{array}{l}\text { 1. New hydro-electric power } \\
\text { plants (HPP) }\end{array}$} \\
\hline 1.1 Morača River HPP project & 0.00 & 0.00 & 0.00 & 0.00 & 0.00 & 0.00 & 2.14 & 2.25 & 2.38 & 2.50 & 2.64 & 2.78 & 2.93 \\
\hline $\begin{array}{c}1.2 \text { Komarnica River HPP } \\
\text { project }\end{array}$ & 0.00 & 0.00 & 0.00 & 0.00 & 0.00 & 0.00 & 0.00 & 0.81 & 0.86 & 0.90 & 0.95 & 1.00 & 1.06 \\
\hline \multicolumn{14}{|l|}{$\begin{array}{l}\text { 2. Revitalization of the exis- } \\
\text { ting HPP }\end{array}$} \\
\hline $\begin{array}{c}\text { 2.1 Revitalization of HPP Piva } \\
\text { Project }\end{array}$ & 0.00 & 0.00 & 0.00 & 0.23 & 0.24 & 0.26 & 0.27 & 0.29 & 0.30 & 0.32 & 0.34 & 0.35 & 0.37 \\
\hline $\begin{array}{c}\text { 2.2 Revitalization of HPP } \\
\text { Perućica Project }\end{array}$ & 0.00 & 0.00 & 0.00 & 0.00 & 0.17 & 0.18 & 0.19 & 0.20 & 0.21 & 0.22 & 0.23 & 0.25 & 0.26 \\
\hline \multicolumn{14}{|l|}{$\begin{array}{l}\text { 3. Thermo-electric power plant } \\
\text { Pljevlja (TPP) }\end{array}$} \\
\hline $\begin{array}{l}\text { 3.1 Revitalization of TPP } \\
\text { Pljevlja I Project }\end{array}$ & 0.02 & 0.06 & 0.07 & 0.07 & 0.07 & 0.08 & 0.00 & 0.00 & 0.00 & 0.00 & 0.00 & 0.00 & 0.00 \\
\hline $\begin{array}{c}\text { 3.2 Construction of TPP Pljev- } \\
\text { lja II Project }\end{array}$ & 0.00 & 0.00 & 0.00 & 0.00 & 0.00 & 0.46 & 0.57 & 0.60 & 0.63 & 0.66 & 0.70 & 0.74 & 0.78 \\
\hline \multicolumn{14}{|l|}{$\begin{array}{l}\text { 4. RSE - Wind Power Plants } \\
\text { Construction }\end{array}$} \\
\hline 4.1 Možura Wind Power Plant & 0.00 & 0.00 & 1.47 & 1.54 & 1.62 & 1.71 & 1.80 & 1.90 & 2.00 & 2.11 & 2.22 & 2.34 & 2.46 \\
\hline $\begin{array}{c}\text { 4.2 Wind Power Plant (new } \\
\text { location) }\end{array}$ & 0.00 & 0.00 & 0.00 & 0.00 & 1.17 & 1.23 & 1.30 & 1.37 & 1.45 & 1.52 & 1.61 & 1.69 & 1.78 \\
\hline \multicolumn{14}{|l|}{$\begin{array}{c}\text { 5. Small hydro-electric power } \\
\text { plants (SHPP) }\end{array}$} \\
\hline 5.1 Construction of SHPPs & 0.00 & 0.00 & 0.00 & 0.00 & 0.76 & 0.80 & 0.84 & 0.89 & 0.93 & 0.98 & 1.04 & 1.09 & 1.15 \\
\hline $\begin{array}{c}\text { 5.2 Revitalization of existing } \\
\text { SHPPs }\end{array}$ & 0.00 & 0.08 & 0.08 & 0.09 & 0.09 & 0.09 & 0.10 & 0.10 & 0.11 & 0.12 & 0.12 & 0.13 & 0.14 \\
\hline $\begin{array}{l}\text { 6. Investments in the energy } \\
\text { efficiency (EE) and incentives } \\
\text { to the EE and RES from the } \\
\text { public sources }\end{array}$ & 0.02 & 0.04 & 0.06 & 0.08 & 0.11 & 0.14 & 0.17 & 0.21 & 0.24 & 0.28 & 0.33 & 0.38 & 0.43 \\
\hline $\begin{array}{l}\text { 7. Construction of Biogas } \\
\text { Power Plant }\end{array}$ & 0.01 & 0.01 & 0.02 & 0.02 & 0.02 & 0.02 & 0.02 & 0.02 & 0.02 & 0.02 & 0.02 & 0.02 & 0.03 \\
\hline \multicolumn{14}{|l|}{ II. INDUSTRY SECTOR } \\
\hline $\begin{array}{l}\text { Aluminium plant (KAP) - } \\
\text { Modernization of Technologi- } \\
\text { cal Process }\end{array}$ & 4.90 & 6.94 & 9.14 & 11.98 & 16.36 & 21.22 & 26.56 & 32.42 & 38.83 & 45.84 & 53.49 & 58.44 & 61.85 \\
\hline \multicolumn{14}{|l|}{$\begin{array}{c}\text { III. AGRICULTURE SEC- } \\
\text { TOR }\end{array}$} \\
\hline Agro-ecological measures & 0.03 & 0.08 & 0.14 & 0.22 & 0.31 & 0.40 & 0.51 & 0.63 & 0.75 & 0.89 & 1.04 & 1.21 & 1.39 \\
\hline TOTAL & 4.98 & 7.22 & 10.97 & 14.23 & 20.92 & 26.59 & 34.47 & 41.68 & 48.71 & 56.38 & 64.73 & 70.43 & 74.64 \\
\hline
\end{tabular}


Table 3. Continued.

\begin{tabular}{|c|c|c|c|c|c|c|c|c|c|c|c|}
\hline PART TWO (2030 - 2040) & 2031 & 2032 & 2033 & 2034 & 2035 & 2036 & 2037 & 2038 & 2039 & 2040 & $\begin{array}{l}\text { Possibility of GHG } \\
\text { emission reduction }\end{array}$ \\
\hline GDP of Montenegro (in mil. $€$ ) & 7.909 & 8.337 & 8.787 & 9.261 & 9.761 & 10.288 & 10.844 & 11.430 & 12.047 & 12.697 & \\
\hline \multicolumn{12}{|l|}{ INVESTMENTS } \\
\hline \multicolumn{12}{|l|}{ I. ENERGY SECTOR } \\
\hline $\begin{array}{l}\text { 1. New hydro-electric power } \\
\text { plants (HPP) }\end{array}$ & 3.09 & 3.26 & 3.43 & 3.62 & 3.81 & 4.02 & 4.24 & 4.47 & 4.71 & 4.96 & $3.91 \%$ \\
\hline 1.1 Morača River HPP project & 1.11 & 1.17 & 1.24 & 1.30 & 1.38 & 1.45 & 1.53 & 1.61 & 1.70 & 1.79 & $1.41 \%$ \\
\hline \multicolumn{12}{|l|}{ 1.2 Komarnica River HPP project } \\
\hline $\begin{array}{l}\text { 2. Revitalization of the existing } \\
\text { HPP }\end{array}$ & 0.39 & 0.41 & 0.44 & 0.46 & 0.48 & 0.51 & 0.54 & 0.57 & 0.60 & 0.63 & $0.50 \%$ \\
\hline $\begin{array}{l}2.1 \text { Revitalization of HPP Piva } \\
\text { Project }\end{array}$ & 0.27 & 0.29 & 0.31 & 0.32 & 0.34 & 0.36 & 0.38 & 0.40 & 0.42 & 0.44 & $0.35 \%$ \\
\hline \multicolumn{12}{|l|}{$\begin{array}{l}\text { 2.2 Revitalization of HPP Perućica } \\
\text { Project }\end{array}$} \\
\hline $\begin{array}{l}\text { 3. Thermo-electric power plant } \\
\text { Pljevlja (TPP) }\end{array}$ & 0.00 & 0.00 & 0.00 & 0.00 & 0.00 & 0.00 & 0.00 & 0.00 & 0.00 & 0.00 & $0.15 \%$ \\
\hline $\begin{array}{c}3.1 \text { Revitalization of TPP Pljevlja } \\
\text { I Project }\end{array}$ & 0.82 & 0.86 & 0.91 & 0.96 & 1.01 & 1.07 & 1.12 & 1.19 & 1.25 & 1.32 & $0.89 \%$ \\
\hline \multicolumn{12}{|l|}{$\begin{array}{l}\text { 3.2 Construction of TPP Pljevlja } \\
\text { II Project } \\
\end{array}$} \\
\hline \multicolumn{12}{|l|}{$\begin{array}{l}\text { 4. RSE - Wind Power Plants } \\
\text { Construction }\end{array}$} \\
\hline 4.1 Možura Wind Power Plant & 2.60 & 2.74 & 2.89 & 3.04 & 3.21 & 3.38 & 3.56 & 3.75 & 3.96 & 4.17 & $3.28 \%$ \\
\hline $\begin{array}{c}\text { 4.2 Wind Power Plant (new } \\
\text { location) }\end{array}$ & 1.88 & 1.98 & 2.09 & 2.20 & 2.32 & 2.45 & 2.58 & 2.72 & 2.86 & 3.02 & $2.38 \%$ \\
\hline \multicolumn{12}{|l|}{$\begin{array}{l}\text { 5. Small hydro-electric power } \\
\text { plants (SHPP) }\end{array}$} \\
\hline 5.1 Construction of SHPPs & 1.21 & 1.28 & 1.35 & 1.42 & 1.50 & 1.58 & 1.66 & 1.75 & 1.85 & 1.95 & $1.54 \%$ \\
\hline $\begin{array}{l}\text { 5.2 Revitalization of existing } \\
\text { SHPPs }\end{array}$ & 0.14 & 0.15 & 0.16 & 0.17 & 0.18 & 0.19 & 0.20 & 0.21 & 0.22 & 0.23 & $0.18 \%$ \\
\hline $\begin{array}{l}\text { 6. Investments in the energy } \\
\text { efficiency (EE) and incentives to } \\
\text { the EE and RES from the public } \\
\text { sources }\end{array}$ & 0.49 & 0.52 & 0.55 & 0.58 & 0.61 & 0.64 & 0.67 & 0.71 & 0.75 & 0.79 & $0.62 \%$ \\
\hline $\begin{array}{l}\text { 7. Construction of Biogas Power } \\
\text { Plant }\end{array}$ & 0.03 & 0.03 & 0.03 & 0.03 & 0.03 & 0.04 & 0.04 & 0.04 & 0.04 & 0.04 & $0.03 \%$ \\
\hline \multicolumn{12}{|l|}{ II. INDUSTRY SECTOR } \\
\hline $\begin{array}{l}\text { Aluminium plant (KAP) - } \\
\text { Modernization of Technological } \\
\text { Process }\end{array}$ & 65.46 & 69.00 & 72.72 & 76.65 & 80.78 & 85.14 & 89.75 & 94.60 & 99.70 & 105.08 & $82.76 \%$ \\
\hline \multicolumn{12}{|l|}{ III. AGRICULTURE SECTOR } \\
\hline Agro-ecological measures & 1.59 & 1.67 & 1.76 & 1.86 & 1.96 & 2.06 & 2.17 & 2.29 & 2.42 & 2.55 & $2.01 \%$ \\
\hline TOTAL & 79.09 & 83.37 & 87.87 & 92.61 & 97.61 & 102.88 & 108.44 & 114.30 & 120.47 & 126.97 & $100.00 \%$ \\
\hline
\end{tabular}

Source: author's calculation

were used. Operating costs of the thermo-electric power plan (TPP) Pljevlja II were considered in line with the newest company studies [34], with the modification of the amount of $\mathrm{CO}_{2}$ compensation according to the estimation of the authors. Namely, the full implementation of the ETS Directive [35] is envisaged from 2026. However, the allowance is also calculated only for calculating the deviation from the obligation to reduce GHG emissions (2.2\% linear reduction rate) in accordance with the ETS Directive.

Regarding actual comparative studies in this area [15], in the next revision of Montenegro's INDC, more investment in renewable energy should be considered (for instance to include installing solar power plants). 
Renewable energy investments promote cleaner energy production, support dynamic growth, and contribute to local societies, including tourism development in the coastal zone of Montenegro.

Structure of investments and the dynamics of their realization are such that the effects of some projects appear already in the first year after the investment, although investments last for a longer period of time. These are the effects of the investments realized in the entire projection period and each year with their partial realization they provide the implementation of some measures and achieve the effects. On the other hand, in some investments the effects occur with the completion of the investment, i.e., the start of the work. For this reason, the budget of the cumulative investment dynamics was performed first and then the calculation of real cumulative investment dynamics for the calculation of the effects.

The socio-economic benefits of investment projects included in the analysis are grouped into two categories:

- Climate benefits (ecological analysis regarding climate change).

- Economic benefits.

\section{Calculating Climate Benefits - Ecological Analysis in the Part of Climate Change}

The calculation of climate benefits was based on the adjusted budgets of the Second National Communication on Climate Change [9]. Within the context of this report, based on various documents, methodologies, guidelines, and adopted strategies, we have determined the possibility of reducing the GHG emissions of each project separately. Implementating measures for these projects will enable sufficient reduction of emissions according to the INDC document, as well as prevent the annual reduction of $1 \%$ of GDP growth according to the Stern Report [36]. For the purposes of the calculations within this analysis, the adjustment of these values had
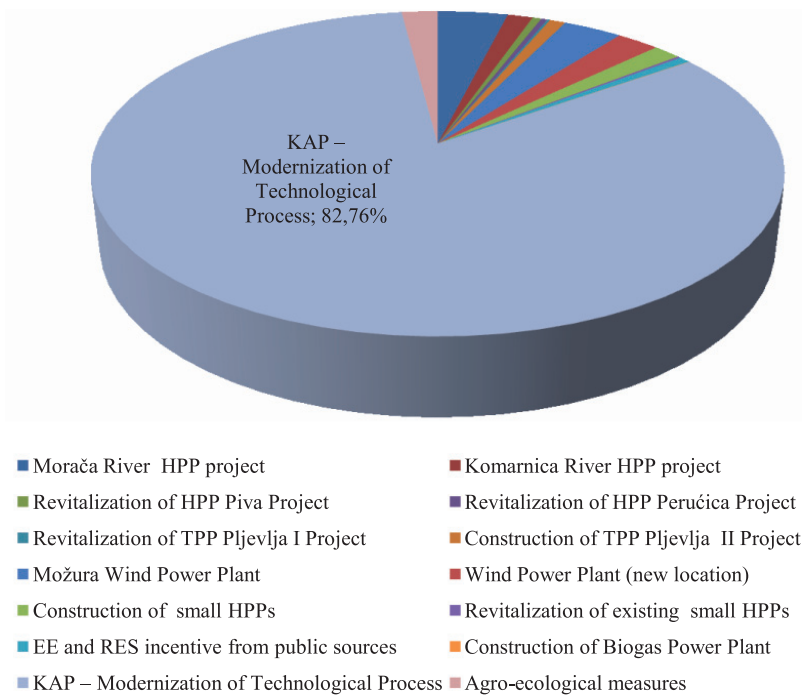

Fig. 1. Participation in estimated climate benefits per investment.

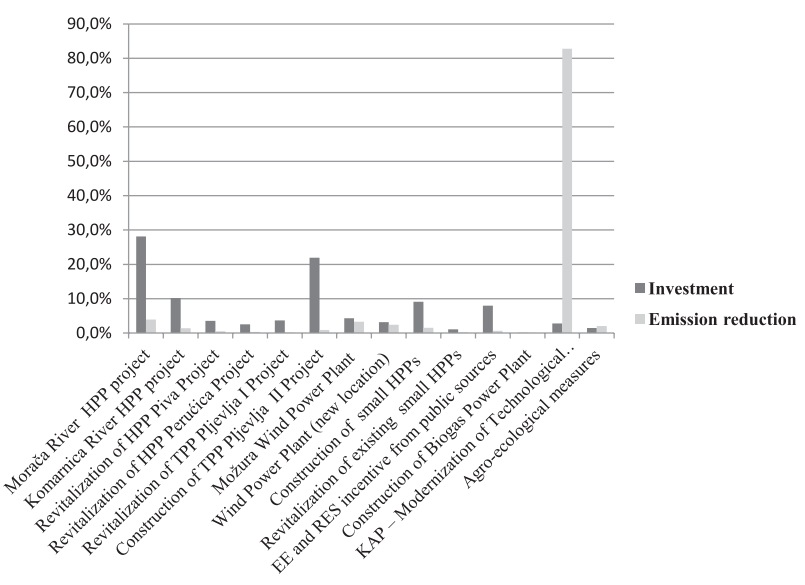

Fig. 2. The ratio of investments and the possibility of reducing GHG emissions per investment.

to be made, i.e., to determine the adequate amounts of emission reduction capabilities in relation to projects that are the subject of this analysis, and in accordance with the respective amounts of investment. This is followed by their participation expressed in percentages of certain projects in total potential of the emission reduction. On the basis of such established participation, in accordance with Stern's report, individual values of climate benefits by projects are calculated as shown in Table 3.

Calculating climate benefits by projects showed that the estimated climate benefits are the highest in investments in the aluminium plan in KAP (82.76\%). The total energy sector contributes $15.20 \%$, while agroecological measures are at $2.01 \%$ of the share as shown in Fig. 1. From Fig. 2 it is obvious that the ratio between the investment and the possibility of reducing GHG emissions is best in the case of KAP.

\section{Calculating Economic Benefits}

In this analysis, calculating the three categories of economic benefits from priority investments for realizating Montenegro's INDC for 2017-30 is as follows:

1) Direct economic benefits

2) Employment benefits

3) GDP benefits

Direct economic benefits are calculated on the basis of direct economic benefit for each project separately from newly created energy or energy savings.

Priority investments in the energy sector in Montenegro are hydroelectric power plants, thermoelectric power plants, and wind power plants, as well as investment projects and incentive measures for energy efficiency and renewable energy sources.

Calculating the benefits of the construction of new hydroelectric power plants and the revitalization of existing hydroelectric power plants was done through their assumed participation of $20 \%$ in responding to the energy needs of Montenegro. Assumed participation in responding to the energy needs of Montenegro for 
energy producers is taken from the Second National Communication on Climate Change [9], while GDP data are taken from the Statistical Office of Montenegro [37]. Energy needs of Montenegro are determined based on the participation of the energy sector in GDP in 2011-15. Then the determined share of participation was increased in line with GDP growth. The benefits were then distributed to projects in proportion to their respective investment values. Real benefits follow the dynamics of investing.

The calculation of benefits of the construction of Pljevlja II Thermoelectric Power Plant (TPP II) and the revitalization of existing TPP Pljevlja I was done through their assumed participation of $12.5 \%$ in responding to the energy needs of Montenegro [9]. The benefits were then distributed to projects in proportion to their respective investment values. Real benefits follow the dynamics of investing.

The calculation of benefits of the construction of wind power plants was done through their assumed participation of $2 \%$ in responding to the energy needs of Montenegro [9]. The benefits were then distributed to projects in proportion to their respective investment values. Real benefits follow the dynamics of investing.

The calculation of benefits of the construction of small hydroelectric power plants and the revitalization of existing small hydroelectric power plants was done through their assumed participation of $2 \%$ in response to the energy needs of Montenegro [9]. The benefits were then distributed to projects in proportion to their respective investment values. Real benefits follow the dynamics of investing.

The calculation of direct economic benefits from $\mathrm{EE}$ investments and the promotion of EE and RES from public sources (including loans and grants) were done as a calculation of benefits in the sectors of industry, transport, services, and households.

The calculation of direct economic benefits in the industry sector (introduction of cogeneration plants) was done through their assumed participation of $1 \%$ in responding to the energy needs of Montenegro [9]. Real benefits follow the dynamics of investing.

The calculation of direct economic benefits in the transportation sector was done with the assumption that the following goals were achieved: transition of bus and passenger car transport from diesel and gasoline to natural gas, and redirecting $50 \%$ of road freight transport to the railway [38].

The quantification procedure for the first-group of benefits in the transport sector was based on data on the annual mileage of buses and passenger cars and the assumption of a transition of $50 \%$ of buses and $20 \%$ of passenger cars to gas (estimation of the authors). Savings costs are calculated based on the differences in the price of diesel and gasoline for buses and combined prices (of diesel and gasoline), and gas for passenger cars. The second group of benefits is calculated by introducing the assumption of redirecting $50 \%$ of road freight traffic to the railway and taking into consideration the data on total road freight traffic - in tons and ton-kilometres [39] (estimation of the authors). The calculation of costs for such a change in road and rail transport, based on data on the average load of transport vehicles/trucks (25 t) and freight trains (500 t), as well as data on VOC (vehicle operating costs) and TOC (train operating costs) has been made in accordance with the existing studies in the transport sector in Montenegro [40], as well in the region [41].

The calculation of direct economic benefits for households was done by quantifying the benefits of saving heating and non-heating energy. The savings in nonheating energy are calculated by taking into account the savings of $150 \mathrm{kWh}$ per household [38] and the price of 0.09 $€ / \mathrm{kWh}$ according to official statistic data. The number of households was obtained from official statistical reports [42]. Heating energy savings are calculated by taking into account the savings for $30 \%$ of households (estimation of the authors) in terms of a reduction in consumption from 80 to $15 \mathrm{kWh} / \mathrm{m}^{2}$ [38]. Data on the total area of housing units of households were obtained from official statistical reports [42].

As for the services sector, the calculation of direct economic benefits was done in a similar way to the household sector, taking into account the same type of investment activities, which in this case refers to facilities in the services sector. For this reason, the benefits are used in proportion to the benefits from the households sector, and in line with the mutual relationship between the estimated investment activities in both sectors.

The direct economic benefits from the construction of a biogas plant are calculated on the basis of data on projected revenues of the public company Deponija the Capital City Podgorica (investor), which are set at an annual level of $€ 670,000$ [43].

The calculation of direct economic benefits in the industry sector focuses on the modernization of the technological process in KAP as done through its assumed participation of $10 \%$ in responding to the energy needs of Montenegro [9]. The benefits were then distributed to projects in proportion to their respective investment values. Real benefits follow the dynamics of investing.

The calculation of direct economic benefits from agroecological measures was done through their assumed participation of $1 \%$ in responding to the energy needs of Montenegro [9]. Benefits are distributed according to projects in proportion to the investment value. Real benefits follow the dynamics of investing.

The effects on employment were determined based on the projected number of newly employed workers in the implementation of projects in question - a total of 723 newly employed workers and average gross wages in the energy sector [44] for the first year of projection. The effects identified in this way were further increased with the projected growth rate of GDP through the projection period. These are the projections of the green job growth (HPPs, SHPPs, wind power plants, biogas plants, and employment growth through various projects in the field of energy efficiency). 
Table 4. Net effects balance.

\begin{tabular}{|c|c|c|c|c|c|c|c|c|c|c|c|c|}
\hline & 2017 & 2018 & 2019 & 2020 & 2021 & 2022 & 2023 & 2024 & 2025 & 2026 & 2027 & 2028 \\
\hline $\begin{array}{c}\text { Investment } \\
\text { expenditures - } \\
\text { CAPEX }\end{array}$ & 88.72 & 173.40 & 237.34 & 358.15 & 420.90 & 184.20 & 176.41 & 27.30 & 16.50 & 16.50 & 16.50 & 13.70 \\
\hline $\begin{array}{c}\text { Operating } \\
\text { expenditures - } \\
\text { OPEX }\end{array}$ & 0.32 & 0.97 & 1.29 & 2.37 & 2.69 & 27.84 & 54.84 & 74.89 & 84.11 & 88.84 & 86.63 & 87.77 \\
\hline Total expenses & 89.04 & 174.37 & 238.63 & 360.52 & 423.59 & 212.04 & 231.25 & 102.19 & 100.61 & 105.34 & 103.13 & 101.47 \\
\hline $\begin{array}{l}\text { Climate } \\
\text { benefits }\end{array}$ & & 4.98 & 7.22 & 10.97 & 14.23 & 20.92 & 26.59 & 34.47 & 41.68 & 48.71 & 56.38 & 64.73 \\
\hline $\begin{array}{c}\text { Direct } \\
\text { economic } \\
\text { benefits }\end{array}$ & & 7.79 & 15.93 & 23.46 & 32.60 & 47.11 & 77.13 & 110.19 & 131.76 & 143.78 & 156.36 & 169.57 \\
\hline $\begin{array}{l}\text { Effects on } \\
\text { employment }\end{array}$ & & 0.35 & 0.66 & 1.17 & 1.55 & 6.53 & 7.24 & 10.46 & 13.29 & 14.43 & 15.66 & 16.97 \\
\hline $\begin{array}{l}\text { Effects on } \\
\text { GDP }\end{array}$ & & 0.64 & 1.22 & 2.16 & 2.87 & 12.09 & 13.41 & 19.38 & 24.63 & 26.74 & 29.01 & 31.44 \\
\hline \multicolumn{13}{|l|}{ Residual value } \\
\hline Total benefits & & 13.75 & 25.02 & 37.76 & 51.25 & 86.65 & 124.37 & 174.50 & 211.36 & 233.67 & 257.41 & 282.71 \\
\hline $\begin{array}{c}\text { NET } \\
\text { EFFECTS }\end{array}$ & -89.04 & -160.62 & -213.61 & -322.76 & -372.34 & -125.39 & -106.88 & 72.31 & 110.75 & 128.33 & 154.28 & 181.24 \\
\hline & 2029 & 2030 & 2031 & 2032 & 2033 & 2034 & 2035 & 2036 & 2037 & 2038 & 2039 & 2040 \\
\hline $\begin{array}{c}\text { Investment } \\
\text { expenditures - } \\
\text { CAPEX }\end{array}$ & 12.20 & 12.20 & & & & & & & & & & \\
\hline $\begin{array}{c}\text { Operating } \\
\text { expenditures - } \\
\text { OPEX }\end{array}$ & 89.23 & 89.65 & 90.45 & 91.41 & 92.61 & 93.51 & 94.91 & 95.75 & 97.55 & 98.35 & 99.25 & 98.95 \\
\hline Total expenses & 101.43 & 101.85 & 90.45 & 91.41 & 92.61 & 93.51 & 94.91 & 95.75 & 97.55 & 98.35 & 99.25 & 98.95 \\
\hline $\begin{array}{l}\text { Climate } \\
\text { benefits }\end{array}$ & 70.43 & 74.64 & 79.09 & 83.37 & 87.87 & 92.61 & 97.61 & 102.88 & 108.44 & 114.30 & 120.47 & 126.97 \\
\hline $\begin{array}{c}\text { Direct } \\
\text { economic } \\
\text { benefits }\end{array}$ & 181.78 & 193.57 & 205.82 & 213.92 & 222.43 & 231.40 & 240.86 & 250.84 & 261.36 & 272.45 & 284.12 & 296.42 \\
\hline $\begin{array}{c}\text { Effects on } \\
\text { employment }\end{array}$ & 18.38 & 19.89 & 21.52 & 22.68 & 23.90 & 25.19 & 26.55 & 27.99 & 29.50 & 31.10 & 32.77 & 34.54 \\
\hline $\begin{array}{c}\text { Effects on } \\
\text { GDP }\end{array}$ & 34.06 & 36.86 & 39.86 & 42.02 & 44.29 & 46.68 & 49.20 & 51.85 & 54.65 & 57.61 & 60.72 & 63.99 \\
\hline Residual value & & & & & & & & & & & & 764.90 \\
\hline Total benefits & 304.65 & 324.95 & 346.28 & 361.99 & 378.49 & 395.88 & 414.22 & 433.56 & 453.96 & 475.45 & 498.08 & 1286.83 \\
\hline $\begin{array}{c}\text { NET } \\
\text { EFFECTS }\end{array}$ & 203.22 & 223.10 & 255.83 & 270.58 & 285.88 & 302.37 & 319.31 & 337.81 & 356.41 & 377.10 & 398.83 & 1.187 .88 \\
\hline
\end{tabular}

Source: author's calculation

The realization of significant infrastructure projects, such as the projects from this analysis, certainly leads to growth in GDP. Indirect and direct impacts of projects on GDP are complex and multifaceted, so most of them cannot be determined with sufficient confidence at this level of socio-economic analysis.
One of the factors that has an undeniable and proven impact on GDP growth is reduction in the unemployment rate. For this reason, in the further analysis we quantified impact on GDP using Okun's law [45], which refers to the empirical link between the employment rate and GDP, indicating that reducing the unemployment rate by $1 \%$ 
leads to an increase in GDP of $2 \%$. The calculations of these impacts have been made based on official data on the registered unemployment rate, the envisaged number of new employees, and projected GDP.

\section{Total Net Effects Balance}

After calculating all the socio-economic benefits of the investments, the table below provides the Net effects balance (Table 4) as the difference between discounted investment and operating costs and socio-economic benefits from investments. The process of discounting the total costs and benefits was done using a discount rate of $5 \%$ [33].

The total net effects balance shows negative net benefits by 2023 (since the calculated total costs are higher than the total socio-economic benefits), after which the projected net effects balance takes a positive trend.

Total net effects calculation has shown that in the structure of total net effects, direct economic benefits (59\%) dominate, followed by climate $(23 \%)$ and other projected benefits as shown in Fig. 3 .

Based on the net effects balance, Figure 4 shows cumulative net effects. The figure shows that the cumulative net effects by 2031 are negative, while from 2031 until the end of the projection period, the cumulative effects take positive values. Year 2031 represents the period of return on total investments.

Based on the net effects balance projection for the period 2017-2040, three basic dynamic indicators of justifiability of investments were calculated (project performance indicators for CBA analysis).

The subject socio-economic analysis of justification of investments has determined that:

- Economic net present value of investments for the projection period $2018-2040$ is positive $(\mathrm{ENPV}=$ $€ 974.98$ million),

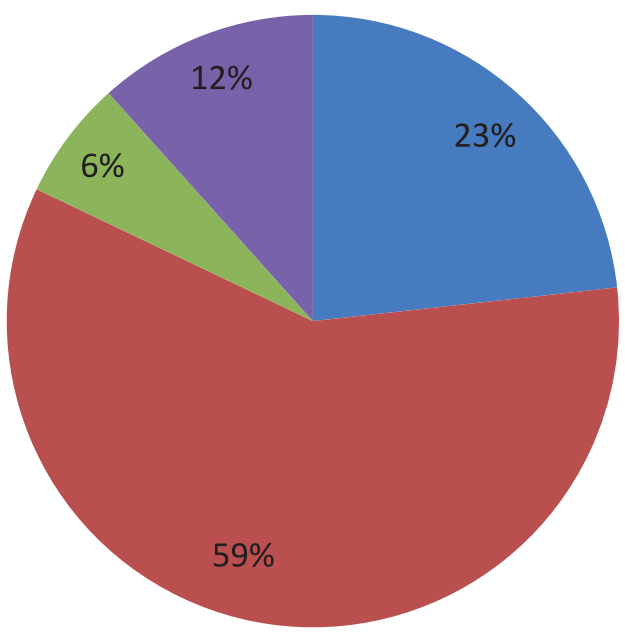

Climate benefits

Effects on emplyment

Direct economic benefits $\quad$ Effect on GDP

Fig. 3. Net effects balance structure.

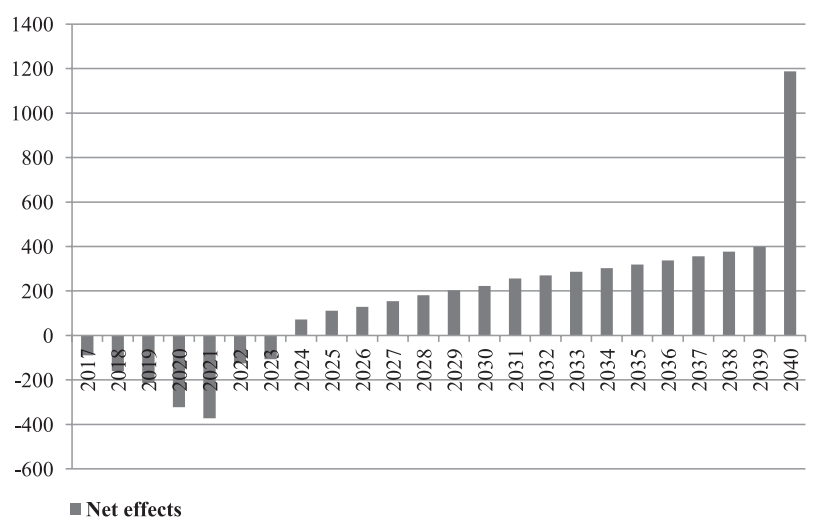

Fig. 4. Net effect balance for the period 2017-40.

- Economic internal rate of return is higher than the defined discount rate of 5\% $(E I R R=10.01 \%)$

- Economic $\mathrm{B} / \mathrm{C}$ ratio is greater than $1(\mathrm{~EB} / \mathrm{C}=1.52)$.

The calculation of the key dynamic indicators of the justification of investments confirms their socio-economic justification, and from a socio-economic perspective, the projects need to be implemented.

In addition, it is important to point out that the planned investments are in line with the preparation of Montenegro's negotiating position for future negotiations with the EU in the area of environmental protection, which is also given in the national strategy with an action plan for transposition, implementation, and enforcement of the EU acquis on environment and climate change 2016-20 [46].

\section{Conclusions}

By ratifying the Paris agreement, Montenegro, as a party of the UN Framework Convention on Climate Change, accepts internationally undertaken commitments in the field of climate change and confirms its dedication to meeting the basic goals of this universal climate action plan. Montenegro's contribution to the international effort to avoid dangerous climate change is expressed in minimum $30 \%$ emission reduction by 2030 compared to the 1990 base year. In line with its INDC, the priority investment plan is prepared accompanied with the socioeconomic analysis which includes the environmental, social, and economic impact assessment of selected investments.

Regarding the priority investment plan and actual comparative studies in this area - in the next revision of Montenegro's INDC, more investment in renewable energy should be considered (for instance to include the installation of solar power plants) [15]. Nevertheless, special attention should be given to the financial schemes of such investments [18].

The conducted analysis was to respond to the set of research questions regarding the long-term economic development goals and strategic development and integration priorities, as well as the ability to accept 
international commitments. Firstly, by selecting priority investments in the period 2017-2030, Montenegro achieves the set target of reducing the emissions of GHGs given in Montenegro's INDC (33.5\%). Secondly, total net effects of selected investments in Montenegro for achieving INDC are positive for the wider community, as confirmed by the performance indicators of the selected projects obtained through the CBA analysis (NPV, IRR, and B/C). Thirdly, priority investments are fully aligned with the key sector priorities given in the Energy Development Strategy by 2030 [38], as well as the National Strategy in the Field of Climate Change by 2030 [10] and the National Strategy for Sustainable Development 2030 (transposition of the UN SDGs 2030 into the national context) [47]. Finally, the obligations arising from the confirmation of the Paris Agreement, which were concretized through the analyzed investment plan, are fully in line with obligations arising from the accession talks with the EU [42] in the area of environmental protection.

\section{Acknowledgements}

This paper contains the research results of project No. 003/2017 funded and supported by UNDP Montenegro.

\section{References}

1. OBERGASSEL W., ARENS C, HERWILLE L., KREIBICH N., MERSMANN F., HERMANN E. OTT E.H. AND WANG-HELMREIC H., Phoenix from the Ashes - An Analysis of the Paris Agreement to the United Nations Framework Convention on Climate Change, Wuppertal Institute for Climate, Environment and Energy, 1, 2016 Available on line https://wupperinst.org/fa/redaktion/downloads/ publications/Paris_Results.pdf (accessed on 12 July 2017).

2. PARIS AGREEMENT, The UNFCCC Decision number $\mathrm{CP}$ 21, Paris, 12 December 2015, Available on line: https://unfccc.int/resource/docs/2015/cop21/eng/109.pdf (accessed on 15 July 2015).

3. UNFCC News Room, Status of the Paris Agreement ratification process, 15 July 2017 Available on line: http://unfccc.int/paris_agreement/items/9444.php (accessed on 15 July 2015).

4. KYOTO PROTOCOL TO THE UNFCCC, Kyoto, Japan, 11 December 1997, Available on line: https://unfccc.int/ resource/docs/convkp/kpeng.pdf (accessed on 1 July 2015).

5. JINNAH S., Makers, Takers, Shakers, Shapers: Emerging Economies and Normative Engagement in Climate Governance, Global Governance 23, 285, 2017.

6. DELLINK R., DEN ELZEN M., AIKING H., BERGSMA E., BERKHOU F., DEKKER T., AND GUPTA J., Sharing the Burden of Financing Adaptation to Climate Change, Global Environmental Change, 19 (4), 411, 2009.

7. COUNCIL OF THE EU, Council conclusions on climate changes, Press Release 568, 2016 Available on line http://www.consilium.europa.eu/en/press/pressreleases/2016/10/11-ecofin-conclusions-climate-change (accessed on 10 July 2017)

8. EUROSTAT, Database, GDP per capita in PPS for 2016, 2017 (http://ec.europa.eu/eurostat/web/products-datasets/-/ tec00114)
9. GOVERNMENT OF MONTENEGRO, the Second National Communication on Climate Change to the UNFCCC, 25, 2015 .

10. GOVERNMENT OF MONTENEGRO, the National Strategy in the Field of Climate Changes till 2030, 2015.

11. EUROPEAN COMMISSION, Montenegro 2016 Report, Brussels, 75, 2016.

12. GOVERNMENT OF MONTENEGRO Intended Nationally Determined Contribution (INDC) of Montenegro, 15 September 2015.

13. UNITED NATIONS FRAMEWORK CONVENTION ON CLIMATE CHANGE (UNFCCC), 1992 Available on line http://unfecc.int/essential_background/convention/ items/6036.php (accessed on 1 July 2017)

14. ELSHENNAWY A., ROBINSON S.H., WILLENBOCKEL D., Climate change and economic growth: An intertemporal general equilibrium analysis for Egypt. Economic Modelling, Part B, 52, 681, 2016.

15. ZOGRAFIDOU E., PETRIDIS K., PETRIDIS N., ARABATZIS G., A financial approach to renewable energy production in Greece using goal programming, Renewable Energy, 108, 37, 2017.

16. SARIANNIDIS N., ZAFEIRIOU E., GIANARAKIS G., ARABATZIS G., $\mathrm{CO}_{2}$ emissions and financial performance of SR firms; The empirical survey of DJSI with a non linear model, Business Strategy and the Environment, 22 (2), 109, 2013.

17. COTTIER T.H., NARTOVA O., SHINGAL A., The Potential of Tariff Policy for Climate Change Mitigation: Legal and Economic Analysis, Journal of the World Trade, 48 (5), 10078, 2014.

18. KARÁSEK J., PAVLICA J., Green Investment Scheme: Experience and results in the Czech Republic Energy Policy, 90, 121, March 2016.

19. ROCHECOUSTE J., DARGUSCH P., CAMERON D., SMITH C. An analysis of the socioeconomic factors influencing the adoption of conservation agriculture as a climate change mitigation activity in Australian dryland grain production, Agricultural Systems, 135, 20, 2015.

20. KYRIAKOPOULOS G., ARABATZIS G. Electrical energy storage systems in electricity generation: Energy policies, innovative technologies, and regulatory regimes. Renewable and Sustainable Energy Reviews, 56, 1044, 2016.

21. STAVINS R.N., Economic Analysis of Global Climate Change Policy: A Primer, KSG Working Papers, 00-003, $1,2000$.

22. BOLLEN J., VAN DER ZWAAN B., BRINK C., EERENS H. Local air pollution and global climate change: A combined cost-benefit analysis, Resource and Energy Economics, 31 (3), 161, 2009.

23. DE LA RUA C., LECHON Y., An integrated Multi-Regional Input-Output (MRIO) Analysis of miscanthus biomass production in France: Socio-economic and climate change consequences, Biomass and Bioenergy, 94, 21, November 2016.

24. JOHANSON P.O., LOFGEN K.G., Disequilibrium cost benefit rules: an exposition and extension. In: FOLMER, H. AND VAN IERLAND E., (editors), Valuation methods and policy making in environmental economics. Elsevier, Amsterdam, 36, 161, 1989.

25. PUTTASWAMAIAH K., Aspects of evaluation and project appraisal. Popular Prakashan, Bombay, 1978.

26. RAJKOVIC D., Role of cost-benefit analysis in evaluation of acception the mineral raw materials exploitation on the environment / Uloga cost-benefit analize u ocjenjivanju prihvatljivosti eksploatacije ležišta mineralnih sirovina 
na okoliš, Symposium Proceedings, International mining symposium Exploration, exploitation and processing of solid raw materials, Springer Business Media Croatia, Zagreb, 372, 2006 [In Croatian].

27. GHASEMZADEH F., ARCHER N.P., Project Portfolio Selection through Decision Support, Decision Support Systems, 29 (1), 73, 2000.

28. POHEKAR S.D., RAMACHANDRAN M., Application of Multi-Criteria Decision Making to Sustainable Energy Planning - A Review, Renewable and Sustainable Energy Reviews, 8 (4), 365, 2004.

29. MEGLIC J., KERN T., URH B., BALKOVEC J., ROBET M. Influence of Polyvalence Professionals on Product Development Process Efficiency, Strojarstvo, 51 (2), 105, 2009.

30. BENNETT F.L., The management of construction: a project life cycle approach, Butterworth-Heinemann, 54, 2003.

31. FABOZZI F.J., PETERSON P.P., Financial management and analysis, Second edition, Hoboken, NJ: John Wiley \& Sons, 2003

32. REGULATION (EU) No 1303/2013 of the European Parliament and of the Council of 17 December 2013 laying down common provisions on the European Regional Development Fund, the European Social Fund, the Cohesion Fund, the European Agricultural Fund for Rural Development and the European Maritime and Fisheries Fund and laying down general provisions on the European Regional Development Fund, the European Social Fund, the Cohesion Fund and the European Maritime and Fisheries Fund and repealing Council Regulation (EC) No 1083/2006, OJ L 347, 2013, Article 101, 320, 2013.

33. EUROPEAN COMMISSION, Guide to Cost-Benefit Analysis of Investment Projects, Economic appraisal tool for Cohesion Policy 2014-2020, 54, December 2014.

34. DELOITTE LLC, Feasibility study of the Thermoelectric power plan Pljevlja II - Project Investment Analysis, Podgorica, 50, 9 August 2016.

35. DIRECTIVE 2009/29/EC of the European Parliament and of the Council of 23 April 2009 amending Directive 2003/87/EC so as to improve and extend the greenhouse gas emission allowance trading scheme of the Community (ETS Directive).
36. STERN N. The Economics of Climate Change, STERN REVIEW, National Institute of Economic and Social Research and HM Treasury, 2006 (available on line http://webarchive.nationalarchives.gov.uk/20080910140413/http:// www.hm-treasury.gov.uk/media/9/9/CLOSED_SHORT_ executive_summary.pdf (accessed on 1 May 2017)

37. MONSTAT Statistical office of Montenegro, GDP Database 2017, Available on line http://monstat.org/eng/page. php?id=19\&pageid=19 (accessed on 10 May 2017)

38. GOVERNMENT OF MONTENEGRO, Energy strategy till 2030, 74, 2014.

39. MONSTAT Statistical Office of Montenegro, Transport database, 2016 Available on line http://monstat.org/eng/page. php?id $=36 \&$ pageid $=36$ (accessed on 10 May 2017)

40. GOVERNMENT OF MONTENEGRO, Studija finansijske i socio-ekonomske opravdanosti auto-puta Bar-Boljare (prioritetna dionica Smokovac-Mateševo)/ A study of financial and socio-economic feasibility of the highway Bar-Boljare (priority road section Smokovac-Mateševo), Podgorica, 2014 [In Montenegrin].

41. MINISTRY OF INFRASTRUCTURE, GOVERNMENT OF REPUBLIC SERBIA AND PUBLIC COMPANY PUTEVI SRBIJE, Priručnik za analizu troškova i koristi / Guide for Cost-Benefits analysis, Belgrade, December 2010 [In Serbian].

42. MONSTAT Household Database, 2017 Available on line http://www.monstat.org/eng/page.php?id=243\&pageid=57 (accessed on 10 May 2017).

43. DEPONIJA Public Utility Company, Feasibility Study of the Construction of Bio Gas Power Plant, Podgorica, 2017.

44. MONSTAT Database on average wages, 2017, Available on line http://monstat.org/eng/page.php?id=24\&pageid=24 (accessed on 12 May 2017).

45. BURDA M. AND WYPOSZ C., Macroeconomics, A European Text, Fifth Edition, 291, 2012.

46. GOVERNMENT OF MONTENEGRO, National Strategy with Action Plan for Transposition, Implementation and Enforcement of the EU Acquis on Environment and Climate Change 2016-2020, Podgorica, 2016.

47. GOVERNMENT OF MONTENEGRO, National Strategy for Sustainable Development 2030, 2016. 